\title{
Tony Wilkinson and the water history of the Near East
}

\section{Citation}

Ur, Jason, and Maurits Ertsen. 2015. Tony Wilkinson and the Water History of the Near East. Water History 7, no. 4: 377-379. doi:10.1007/s12685-015-0149-3.

\section{Published Version}

doi:10.1007/s12685-015-0149-3

\section{Permanent link}

http://nrs.harvard.edu/urn-3:HUL.InstRepos:30367411

\section{Terms of Use}

This article was downloaded from Harvard University's DASH repository, and is made available under the terms and conditions applicable to Open Access Policy Articles, as set forth at http:// nrs.harvard.edu/urn-3:HUL.InstRepos:dash.current.terms-of-use\#OAP

\section{Share Your Story}

The Harvard community has made this article openly available.

Please share how this access benefits you. Submit a story.

Accessibility 
Ur, Jason A., and Maurits Ertsen. 2015. Tony Wilkinson and the Water History of the Near East. Water History 7:377-379. http://link.springer.com/article/10.1007\%2Fs12685-015-0149-3

\title{
Tony Wilkinson and the Water History of the Near East
}

\author{
Jason Ur, Harvard University
}

Maurits Ertsen, Delft University of Technology

\begin{abstract}
Water figured centrally throughout Tony Wilkinson's spectacular career in landscape archaeology in the Near East. His case studies ranged geographically from Yemen to Turkey, Syria to Iran; they included arid desert fringes and (relatedly) moist foothills. The water systems he studied varied in scale from households to villages to states, with a general trend through time from small selforganized systems to massive imperial schemes. Wilkinson drew on any discipline from which data were available, and from which a collaborator or two could be procured. In all cases, however, empirical data from field archaeology held the central position. Despite the scale and number of his projects, collaborations, and students, these field data were overwhelmingly obtained by Wilkinson himself, often under the most challenging weather conditions, made necessary by local agricultural and university academic calendars - negotiating between when fields were clear and courses needed to be taught.
\end{abstract}

Wilkinson often tackled the traces of daily life, the kinds of land use that occurred outside of the interest or notice of the palace elite that have consumed most of the attention of archaeologists. Some of his earliest research investigated falaj (qanat or karez) systems on the Omani coast, which fed sunken fields and powered mills in small oasis towns. He returned to the Arabian peninsula, to trace the small-scale runoff irrigation systems that fed the terraces of highland Yemen. His most widely cited scholarship, however, revolved around the dry-farming agricultural systems that sustained the earliest cities in northern Mesopotamia. He demonstrated how inter-annual variability in rainfall, and household-based adaptations via manuring, imposed a ceiling on urbanization. Wilkinson's model (Wilkinson 1994) was a deft combination of empirical field data, ethno-historic reports, and modern instrumental data on rainfall and crop productivity, and it remains the best understanding of the operation of Early Bronze Age subsistence.

The water systems of the late empires of the Near East were not outside of his interests, of course. In separate projects, he traced Hellenistic and Islamic canals on the Balikh River in Syria, the Nahrawan and associated canals of Abbasid Samarra, and enormous water systems of the Sasanian empire on the Khuzistan and Gorgan plains of Iran (Wilkinson and Rayne 2010). In his recent work, as shown in this issue of Water History, he combined his interest in small-scale water systems and the efforts by large empires.

Wilkinson's methods evolved over his career, but one element remained essential: intensive field observation, controlled collection and analysis of surface artifacts, and geo-archaeological study of soils and sediments. Several generations of students from Chicago, Edinburgh, and Durham were introduced to landscape archaeology by following him up tells and terraced hills, and down into abandoned canals and any other open hole that might provide a good stratigraphic section, regardless of what might be decomposing at its bottom. Wilkinson was quick to incorporate new technologies, such as Global Positioning Systems (GPS) receivers, satellite remote sensing, and Geographical Information Systems (GIS) software, although he rarely mastered them himself. Most often, he pushed his students to use these new technologies to approach some of the issues he had 
studied earlier. A good example comes from the 1998 public availability of photographs from the CORONA intelligence satellite program. Wilkinson was one of the first to recognize its utility to landscape archaeology, and several of his students have now made careers out of extending his work on ancient settlement patterns, trackways, and irrigation systems via CORONA-based broadarea studies, starting from Wilkinson's initial suggestions.

Wilkinson's work with students was part of his philosophy of collaboration. Most prominently, he worked closely with excavators and experts on the material culture of the region. Many of "his" field projects fell under the aegis of a long-running site-based excavation, and he always regarded survey and excavation data to be complementary. On his surveys, he was quick to involve micromorphologists, geologists, remote sensing specialists, illustrators, epigraphers, and historians, as well as excavators. He was generous with publication rights; a glance at his publications through time shows a steady increase in the number of coauthors for books and journal articles.

Wilkinson's tremendous field dataset, broadly stretched across time and space, led him in three late career directions. It enabled him to synthesize some eight thousand years of human landscape history in his Archaeological Landscapes of the Near East (2003). It introduces the concept of the "signature landscape," a durable combination of environmental and cultural features that tended to recur across time and space in the Near East. Despite the geographical and thematic range of its case studies, every chapter is drawn largely from Wilkinson's own field research, although the casual reader might not realize it from the text or even from the bibliography (Wilkinson was remarkably resistant to self-citation in all but the most obligatory contexts). He also began developing dynamic agent-based models to test his earlier ideas about the growth of settlements under dry farming and irrigation, now explicitly drawing on the concepts of self-organization and emergence. This NSF-funded project ultimately involved more than a dozen collaborators from many disciplines and institutions (Wilkinson et al. 2013). Most recently, he began to write the settlement history of the entire ancient Near East in the Fragile Crescent Project (Wilkinson et al. 2014). This collaborative effort had already begun to produce the latest generation of students, who will continue his intellectual legacy.

\section{References}

Wilkinson, T.J. 1994. The Structure and Dynamics of Dry-Farming States in Upper Mesopotamia. Current Anthropology 35:483-520.

- 2003. Archaeological Landscapes of the Near East. Tucson: University of Arizona Press.

Wilkinson, T.J., McGuire Gibson, and Magnus Widell. Editors. 2013. Models of Mesopotamian Landscapes: How Small-Scale Processes Contributed to the Growth of Early Civilizations. BAR International Series 2552. Oxford: Archaeopress.

Wilkinson, T.J., Graham Philip, Jenny Bradbury, R. Dunford, Daniel Donoghue, N. Galiatsatos, Daniel Lawrence, Andrea Ricci, and Stefan L. Smith. 2014. Contextualizing Early Urbanization: Settlement Cores, Early States and Agro-pastoral Strategies in the Fertile Crescent During the Fourth and Third Millennia BC. Journal of World Prehistory 27:43-109.

Wilkinson, T.J., and Louise Rayne. 2010. Hydraulic Landscapes and Imperial Power in the Near East. Water History 2:115-144. 